\title{
Setting the record straight
}

In the Volume 5, No 4 of The Journal of Brand Management, a paper by Ward and Perrier included a substantial misconception of the development of Sony. Among other things on page 286 the paper stated that Sony's principal business is its music, while products such as Walkman, Discman, Trinitron TVs etc are 'NPD'. This is almost the exact opposite of the truth.

To set the record straight, Sony was founded in 1946. The original prospectus written by the late Honorary Chairman Masaru Ibuka included the following vision:

'We shall be very selective of our products and even welcome technological difficulties. We shall focus on technologically sophisticated products of greatest usefulness to society, regardless of the quantity involved. Moreover, we shall avoid the formal demarcation between electronics and mechanics and shall create products uniting the two fields, that are unique and that other companies cannot overtake.'

In fulfilling this mission Sony developed a progressive range of world beating, ground breaking electronic products including tape recorders in the 1940s, the first transistor radio in the 1950s, the first transistor TV in the 1960s. The breakthrough Trinitron
Colour TV was launched in 1968 and has been the single most important Sony product. Betamax was launched in the 1970s and the Walkman in 1979. The Compact Disc was launched by Sony and Philips in 1982 . Based on the Betamax experience, and that of the launch of CD, Sony decided it needed a closer understanding of the 'software' and so bought CBS Music in 1986, later renaming it, Sony Music, which now accounts for less than 10 per cent of total sales. All this is in the public domain and the proportion of sales revenue by major product category is published in every Annual and Quarterly Report.

I make these points because I care about the Sony brand and always will. However, after 10 years I have decided to leave Sony and am taking up a senior position with the Pentland Group plc where I shall have international responsibility for some of their major brands including Speedo, Ellesse and Berghaus. Having been Country Manager for one of the world's greatest corporate brands it will be fascinating to move back into a portfolio environment and develop more targeted positions in the sporting and leisure apparel industry against the monolithic Nike and Adidas.

David Pearson Editorial Board 